Journal of Sustainable Development of Transport and Logistics

journal home page: https://jsdtl.sciview.net

Nze, O. N., Okeudo, G. N., \& Ejem, E. A. (2021). Trend analysis of the productivity of Nigerian seaports. Journal of Sustainable Development of Transport and Logistics, 6(2), 81-95. doi:10.14254/jsdtl.2021.6-2.5.

\title{
Trend analysis of the productivity of Nigerian seaports
}

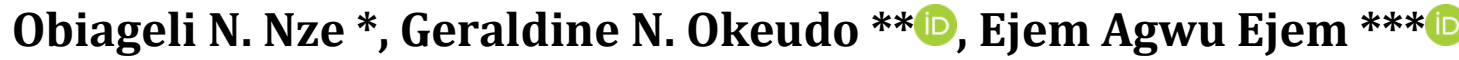

\author{
${ }^{*}$ National Centre for Technology Management, \\ South-East Zone, Enugu, Nigeria \\ ${ }^{* *}$ Federal University of Technology, \\ Owerri, Imo State, Nigeria, \\ Department of Logistics and Transport Technology \\ ${ }^{* * *}$ Federal University of Technology, \\ Owerri, Imo State, Nigeria \\ Department of Supply Chain Management \\ ejemflagospel@yahoo.com
}

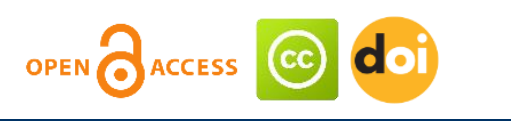

\section{Article history:}

Received: September 15,

2021

1st Revision: September 21,

2021

Accepted: November 16, 2021

\section{DOI:}

10.14254/jsdtl.2021.6-2.5
Abstract: This paper assessed the trend of productivity of the existing six Nigerian ports. Secondary data was extracted from National Bureau of Statistics (NBS) Annual Reports, Nigeria Port Authority (NPA) Annual Reports, and Central Bank of Nigeria (CBN) Annual reports. Using the Data Envelopment Analysis technique, it was discovered that Calabar Port had been under-utilized towards the achievement of the required results. On the contrary, Rivers Port requires technical touches in her operations. As a liquid bulk port, the time of loading and discharging of commodities are often more than any other type of port and the turnaround time at this port are often more. Scale optimization is also required in Rivers Port. Inferentially, Lagos Port has been operating on optimal scale size but fluctuating managerial efficiency was experienced in the operation years. As a matter of findings, Tin Can Island has a similar trend to that of Onne Port with low productivities in the pre-concession period which improved consistently in the postconcession year of 2010 till the year 2015. It was also observed that Tin Can Island Port operated on under-utilization of inputs resources in the pre-concession periods till the post-concession year 2010. This reflects the element of wastefulness concerning both inputs and outputs quantities. Delta Port experienced fluctuating scale and technical efficiency trends in both pre and post concession years. Hence, it is observed that productivities' trends vary among the concessioned Nigerian Ports. These could be as a result of the influence of varied exogenous and endogenous factors on individual Port.

Keywords: trend analysis, productivity, seaports, concessioning, technical and scale efficiency 


\section{Introduction}

Nigerian Seaports have been serving the main purpose of transferability of larger quantities of spatially distributed commodities in Nigeria and other neighbouring landlocked countries to designated geographical locations and transferability of required commodities from other countries to Nigeria and other neighbouring West African countries i.e., Nigerian Seaport takes 50\% of export trade from Nigeria and $70 \%$ of the importation to Nigeria (Nigerian Ports Authority, 2015). Concerning accessibility to high capacity and frequency global maritime freight transport system. African Bank (2010) ranked Nigeria $50^{\text {th }}$ position internationally, $4^{\text {th }}$ position in Africa and $1^{\text {st }}$ position in West Africa and over Sub-Sahara African countries with liner shipping connectivity index (LSCI) 13.7, 18.3 and 19.9 in 2007, 2008 and 2009 respectively. Thus, Nigerian Seaports have been playing a vital role in the growth of the Nigerian economy and also the West African economy as a whole in the area of international transactions and trade.

Hence, this significant importance of Nigerian seaports warrants adequate and consistent management of their resources (input mix) for sustainability and the resultants of the management can be measured via their performances or productivities over time. Port as a system comprises a cascade of operations ranging from land operations to terminal operations and its productivity is not only a concern to individual stakeholders but a mutuality between port authorities, private terminal operators, logistics operators (freight forwarders), and large shippers e.tc. Generally, Port productivity is made of three components namely terminal/berth productivity, yard productivity and land productivity, thus these components have respective indicators of measurement. Therefore, it is crucial to ascertain how to port's resources are being utilized in the individual area of productivity just as Chung, 1993 stated that progressive port manager always desires to know how extensively and intensively port assets are being utilized as well as how well the operations perform financially in terms of port productivity indicators.

However, the evolution of containers, larger vessels sizes incorporated with speedy trends in the maritime world have been sources of challenges for ports operators to satisfy their consumers thus, compelling ports/terminals operators to expand their capacity by employing updated forms of technologies with the expansion of infrastructure and superstructure to accommodate the trending vessel sizes, larger quantities of cargoes and to speedily evacuate cargoes. These trends have been great challenges to many African ports and treats to their productivities as they strive for survival in the maritime markets. As some Ports struggle with their limited resources, they found it challenging to increase their limited capacities. Hence, Nigeria was one of the African countries that were saddled with the responsibilities to increase her Ports' capacities. In other to stay competitive, the Nigerian port system witnessed a significant reform which saw most of the Nigerian Ports' terminals concessioned to private operators in 2005/2006. The public-private partnership as corroborated by (Drewry Maritime Research, 2017), is a mechanism to leverage greater private investment participation in port development and most importantly, to access specialized skills, innovations, and new technologies associated with infrastructure development, operation and maintenance. Based on this reform, the last year of the contract is 10 years and some terminals were concessioned on 25 years of contractual period (NPA, 2015). This reform has attracted the interest of both internal and external parties on the effects of concession instruments on improved ports' productivities and also the assessment of Nigerian ports' productivities has become a cynosure towards every individual.

We are burdened on how to ascertain an insight evaluation of the productivity of ports in Nigeria through concessioned terminals despite the underlying complexities surrounding the systems vis-à-vis their differences in terms of operation, location, structure etc. and how to solve the mediocrity resulting from concessioning. To ascertain the productivities changes that have occurred since the commencement of concession at individual Nigerian ports, assessment of the productivities of these ports is required following the objectives of concessioning. Therefore, this paper aims at ascertaining the improvements that have been witnessed in the Nigerian port system so far by assessing the trend and horizontal analysis of Nigerian port's productivities from the pre-concession era (the year 1985) to post-concession (the year 2015). 


\section{Literature review}

Productivity is comprised of two divisions; total factor productivity (TFP) and partial productivity. Eatwell and Newman (1991) captioned total factor Productivity as multifactor productivity which is required where a broad total collection of outputs and inputs are required. Production theory is the basis for analyzing output level changes and the rate of output depends on these factors; the rate at which inputs (technology) are utilized, the amount and types of input resources injected and the level of technology or kind of production process that is employed. Robert and Marc (2009) described productivity as a key to determining the optimal combination of input that should be used to manufacture a given product. Gboyega (2005) further explained the variations in total factor productivity by differences in productivity efficiency, the scale of production and the level of technology while Antle and Capalbo (1988) identified two major approaches of total factor productivity measurement as the growth accounting i.e., Index number and the econometric approach.

According to them, the growth accounting approach to TFP measurement is a method for calculating the contribution of various factors to economic growth with the aid of marginal productivity theory - growth accounting decomposes the growth of output into - growth of labour, land, and capital; education; technical knowledge and other miscellaneous sources while the econometric approach to TFP measurement is the calculation of specified production function with the intention to creating the direct connection of productivity growth to important parameters of either of the functions. Its econometric implementation provides parameters estimates of the production technology in the process of measuring productivity advancement.

In productivity measurement the main indicator of improved productivity becomes a decreasing ratio of input to output at the constant or improved quality this is also be buttressed by Kumar and Suresh (2009) who asserts that measuring the productivity of different groups of operatives requires different ratios which are indicative of output/input relationship by citing an example of the productivity of assembly line work which could be measured as output units per man-hour or the value of good produced per cost of labour on an assembly line. The main problem of productivity is clustering and the solution is the reduction of the size of the clustering considering the kind of choice to be implemented between applying parametric and non-parametric productivity measurement. Udabah (2000) opined that productivity is a very essential tool for rapid economic growth. He further discussed the two important sectors in Nigeria which could have up-heaved the economic growth of the nation which he mentioned transportation especially port as one of the sub-sectors which has the potentials to aid these sectors and links them with international trade. Furthermore, he opined that there should be a cordial relationship between productivity, economic growth and development.

Productivity can also be described as the process by which varieties of inputs are applied for the processing of a system to obtain the desired or required outputs at another end. Indeed, productivity is more of a result of a complex social process involving science, research, analysis, training, technology, management, production plant, trade union and labour among other inter-related influences (Gboyega, 2005). In studying production functions, Robert and Marc (2009) opined that there are two important relations between inputs and outputs which are crucial. One is the relation between input and variation in all inputs taken together. This is known as the return to scale characteristics of a production system. Return to scale plays an important role in managerial decisions. They affect the optimal size of a firm and its production facilities. They also affect the nature of competition and thus are important in determining the profitability of an investment. It also signals the relationship between the quantity of an individual input (or factor of production) employed and the level of output produced.

Kumar and Suresh, 2009 defined the purposes of studies of productivity for improvement purposes based on the following types of analysis such as trend analysis, horizontal analysis, vertical analysis and budgetary analysis. Furthermore, they defined trend analysis as the studying of productivity changes for the firm over a while, horizontal analysis as the studying of productivity in comparison with other firms of the same size and engaged in a similar business, vertical analysis as the studying of productivity in comparison with other industries and other firms of different sizes in the same industry and budgetary analysis as setting up a norm for productivity for a future period as budget, based on studies as above, and planning strategies to achieve it.

The efficiency of the use of resources or productivity performance is of key interest thus high productivity in transportation, industry, agriculture and other service sectors are necessary for the 
rapid economic growth of any nation. Productivity can be referred to as a matrix of the technical or engineering efficiency of production. As such quantitative metrics of input and sometimes output is emphasized. Productivity is distinct from metrics of allocative efficiency which take into account both the value of what is produced and the cost of input used, and also distinct from metric of profitability, which addresses the difference between the revenues obtained from the output and the reference associated with consumption (Courbois \& Temple, (2001); Kurosawa (2000); Pineda (1999) and Saari (2006)). The activity of converting input resources into service(s)/product(s) can be identified with production and consumption. Thus, production is a process of combining immaterial and material inputs of production to produce tools for consumption. The methods of combining the inputs of production in the process of making outputs are called technology. Technology can be depicted mathematically by the production which describes the function between inputs and outputs. The production function depicts production performance and productivity as the metric for it. Measures may be applied with, for example, different technology to improve productivity and to raise production outputs. With the help of production function, it is possible to describe the mechanisms of economic growth.

The process of productivity measurement is complex as Beskovnik (2008) said because of the interrelationship of the different elements that make up a terminal and they have different impacts on each other. Container handling productivity as Beskovnik (2008) viewed is directly proportionate to the transfer functions of a container terminal, the number and movement rate of berth cranes, the use of yard equipment, berth and yard occupancy, number of vehicles at the entrance into the terminal, the productivity of workers employed at the operational areas of the terminal which he opined for frequent check-up and adjustment.

There may be differences in the case of other types of cargo terminal such as dry cargo terminal, liquid cargo terminal etc. Tongzon and Heng (2005) further described port productivity as a measure of the efficiency of port or terminal operations and consider the amounts of resources usually necessary to perform a specific task in a given period. They stated that the level of efficiency indicates how quickly containers are handled and how quickly vessels are served and turn around at port. Considering the port (terminal) operation efficiency level, carriers view ships time at ports as an expensive activity thus the speed of container handling and consequent vessel turnaround time is a crucial issue in terms of competitiveness for port authorities and port operators. NPA (2012) examined the growth of Lagos Port Complex and Tin Can Island Port as the major development in Apapa, Lagos state and Nigeria in general. The report described the effectiveness of a seaport as a function of the speed and ease by which cargo passes through the port. The study mentioned throughput as one of the measurements of the operational effectiveness of the port. This can be in terms of port performance index (PPI), berth performance index (BPI) or cargo performance index (CPI). The time of waiting at berth or port premises can also be used to measure the operational effectiveness of the port. The effectiveness of the port will contribute in no small measure to the economic prosperity of its location and the nation. Thus, apart from the benefits derivable from the port as a viable economic base through the value chain, its effectiveness is important to optimize the advantages.

Furthermore, Chung (1993) is of the view that exporter/importer assess the port's performance through one indicator of interest which is the dwell time of cargo in port measured in terms of the number of days that a ton of cargo remains in port. A high dwell time is generally an indication that all is not well with the port. It does not identify areas, where improvements may be sought since, unlike ship time in port, it does not have a breakdown according to the various procedures that have to be gone through before cargo, can be shipped or delivered (e.g., customs clearance, waiting for instructions, waiting for the ship, waiting for transport, etc.). The importance of dwell time also obviously varies with the nature of the cargo. Hence substantial productivity improvement is generally needed to enable ports to meet the strict service requirement of their customers and to obtain competitive advantages. Tongzon and Heng (2005) concluded that the higher the efficiency level of a port or terminal operation, the more port users are likely to select it as their call port which in turn will make the port gain more market share (revenue). They opined that the reliability of port operations also influence a port's performance which in turn will affect the choices of shipping lines and shippers. Reliability means a steady and predictable performance adapted to shipping lines schedules. If a port authority or port operator always makes delays during the operation process due to strikes, equipment breakdown, weather, e.tc, shipping Lines and shippers will suffer huge losses due to these kinds of unreliability. Carriers and shippers will 
not desire to call at this kind of port even if they provide the most attractive price among their competitors. The differentiation into productivity indices is informative as it helps to identify the source of productivity change for instance; it would be a waste of management focus, effort and resources if a seaport or container terminal which already utilizes its existing production facilities to justify the corrigenda to efficiency deficiencies and unconsciously postpones a technological investment program. However, the offered efficiency and productivity indices should not be interpreted uncritically, as they may be influenced by endogenous and exogenous factors Odeck and Schøyen (2009). He deduced from his findings on the relative efficiency and productivity of Norwegian ports and also productivity comparison with U.K Ports and other Nordic Ports thus throughput is an operational performance indicator that may not be adequate to measure productivity when considering some input variables. This can also complement financial indicators.

Marlow and Paixao (2003) argued that poorly performing ports that are cost inefficient may have to increase their port prices to cover costs and thus to break even (where revenue covers costs), thereby possibly placing the ports on competitive price disadvantage, or else held constant. They further opined that when ports are technically inefficient which could result in ships staying in port longer Shipping lines may have to introduce more ships on a given trade route to meet their scheduled port calls on the route and also when cargoes stay at the ports longer, shippers may have to increase their inventories, resulting in higher inventory costs. Ineffective ports may have lower profits as a consequence, thereby having less profit to finance port investments.

Global terminal operators must strive to increase productivity at the ports considering the current market condition where time is essential thus the introduction of much larger vessels will create a big gap in supply and demand (Kavas, 2016). She supported the use of ship arrival and departure from the berth as the base for measuring port productivity and argued that increase in productivity at the port and improvement on vessel turnaround time is not solely dependent on automation of cargo handling although it helps to reduce the labour cost to an extent but have not enabled vessel operator to acquire the expected results from the ports. Hence, he opined that labour, crane numbers infrastructure, capital management, policies and government agencies' involvements should be considered other than automation.

Golany and Roll (1989) expressed those ports have evaluated their performance by comparing their actual and optimum throughputs (measured in tonnage or number of containers handled). He concluded that if a port's actual throughput approached (departs from) its optimum throughput over time, its performance would improve (deteriorated) over time. He defined effectiveness as to how well the port utilizes its available resources or concerned with how well the port provides throughput service to its users i.e. carriers (ocean and inland) and shippers thus classified economic operating objectives of a port as either efficiency or effectiveness objectives in which port efficiency operating objectives include the technical efficiency objective of maximizing throughput in the employment of a given level of resources (exhibited by the port's economic production function) and the cost efficiency objective of minimizing cost in the provision of a given level of throughput (exhibited by the port's economic cost function). For a port to be effective, it must be efficient i.e. it must be cost efficient which in turn requires that it must be technically efficient. For example, if a port has the effective operating objective of maximizing profits and is cost inefficient, it can obtain greater profits for the same level of throughput service by reducing its costs to become cost efficient. A port can be cost efficient without being effective implies that a port may attract revenue/throughput when it has a reduced or subsidized cost even when it is not effective.

\section{Methodology}

The areas of study are the Ports and mainly terminals of Nigeria Ports since the port productivity substantially depends on the operations carried out at each concessioned terminal. Therefore, the six (6) Nigeria Ports represent decision-making units (DMUs., homogenous groups or units need to perform similar tasks and objectives under the same set of market conditions and the factors (inputs and outputs). Larger DMUs can capture higher performance the number of DMUs should be at least twice the number of inputs and outputs. The variables had already been measured, aggregated and categorized by Nigeria Port Authority and their respective values were collated separately from each terminal operator from different port: six (6) major geopolitical ports. The input variables are ship 
traffic, vessel traffic, berth efficiency and turnaround time while outputs are throughput obtained and revenue generated.

\begin{tabular}{lccc}
\multicolumn{4}{l}{ Table 1: Nigerian Ports and their locations } \\
S/N & Location & DMU & Ownership \\
\hline 1 & Western Nigeria & Lagos Port Complex & Landlord concession \\
2 & Western Nigeria & Tin Can Island Port Complex & Landlord concession \\
3 & Eastern Nigeria & Delta Port Complex & Landlord concession \\
4 & Eastern Nigeria & Rivers Port Complex & Landlord concession \\
5 & Eastern Nigeria & Calabar Port Complex & Landlord concession \\
6 & Eastern Nigeria & Onne Port Complex & Landlord concession \\
\hline
\end{tabular}

Source: NPA, 2015

The secondary data obtained from the ports in Table 3.1 was analyzed with data envelopment analysis (DEA) incorporated with technical efficiency (TE), scale efficiency (SE), constant return to scale input-oriented analysis (CRS input-oriented), constant return to scale output-oriented analysis (CRS output-oriented), variable return to scale input-oriented analysis (VRS input-oriented), variable return to scale output-oriented analysis (VRS output-oriented). The Jensen Operations Research (OR) Software for Transportation modelling and problems was used for the analysis. It is a Microsoft Excel add-in programme. SPSS was also used extensively in the research. The DEA solver determines the benchmark terminal by comparing the terminal's efficiency with other terminal operators' efficiencies and its efficiency. If the terminal has 1 against itself the DEA efficiency implies it is $100 \%$ efficiency.

\section{Results and discussion}

\subsection{Trend analysis of Lagos port complex productivity}

Figure 1: CRS - Technical Efficiency (input-oriented) and CRS - Scale Efficiency (input-oriented) at Lagos Port Complex from 1980 - 2015

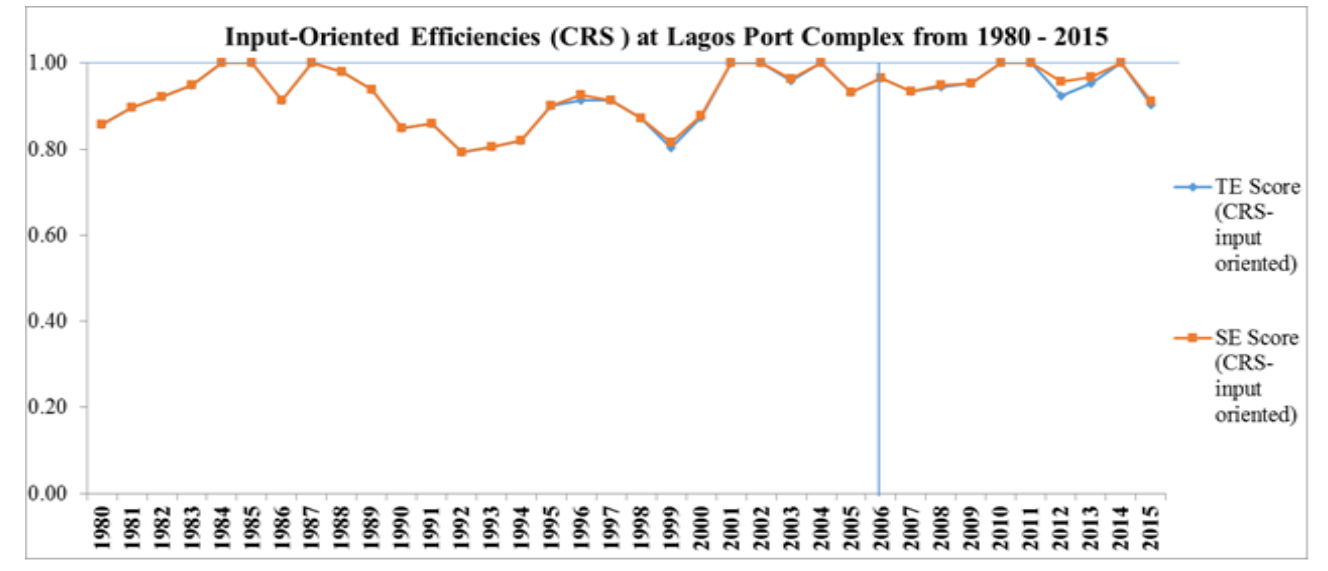

From Figure 1, it can be deduced that there was a fluctuation in both technical and scale efficiencies at Lagos Port Complex throughout the pre-concession era of its operation years (19802005). During the 1980s era, higher productivities were recorded in the operation years 1984, 1985 and 1987 with technical efficiency and scale efficiency scores of (1.0) but unfortunately declined steadily to low technical efficiency and scale efficiency scores of (0.79) in 1992 and productivity did not improve beyond TE score of (0.91) and SE score of (0.93) which was attained in the operation year 1996 in the 1990s era. However, the productivity improved with TE and SE scores of (1.0) in 2001 from a low TE and SE of (0.80) and (0.82) respectively in 1999. The port was also efficient in scale and technically efficient in the preceding operation years 2002 and 2004 with TE and SE scores of (1.0). Though, the port still had a fluctuating manner of productivity during the post-concession era with the most technical and scale efficient operation year in 2010, 2011 and 2014 with TE and SE scores of (1.0) and the least technical and scale efficient year in 2015 with TE score of (0.90) and SE score of (0.91). 
Figure 2: CRS - Technical Efficiency (Output-oriented) and CRS - Scale Efficiency (Outputoriented) at Lagos Port Complex from 1980 - 2015

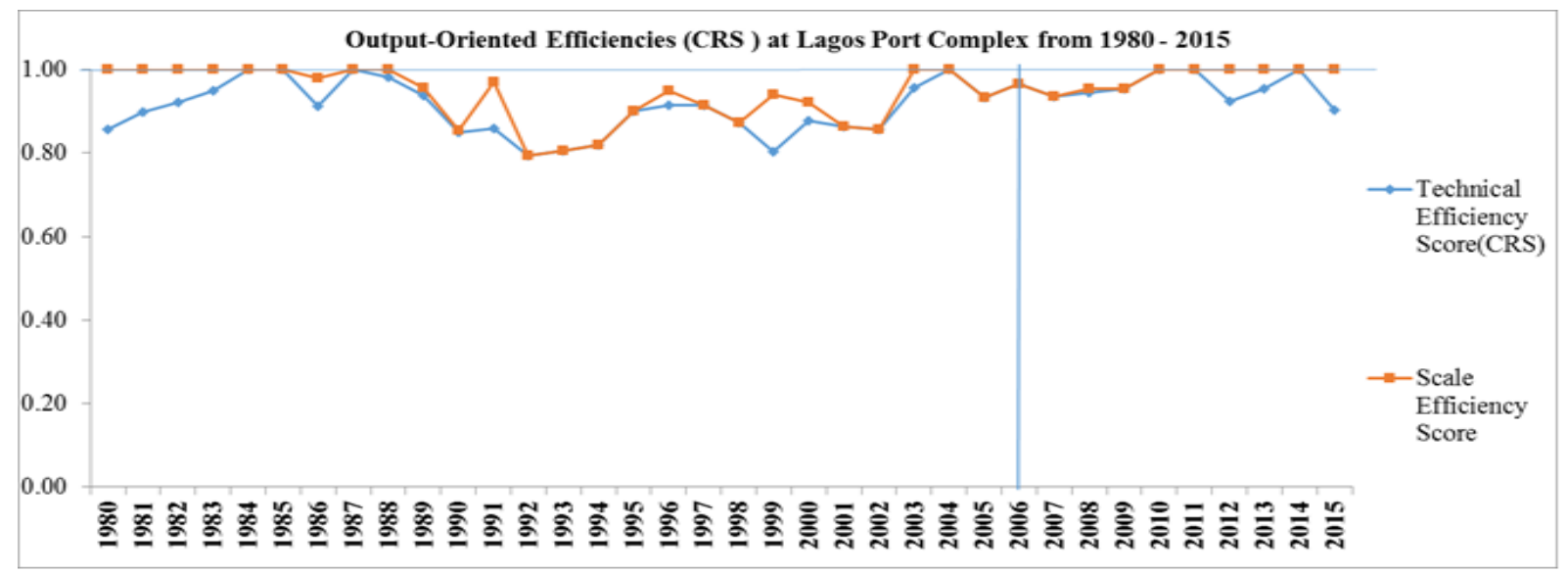

From Figure 2, it is observed that Lagos Port Complex was scale efficient with a score (1.0) in the production periods of 1980 to 1985 but technically inefficient in the production period of 1980 to 1983 with TE Scores of (0.86), (0.90), (0.92) and (0.95) respectively. Though, the trend shows that there was technical progress in the production function of this port from the year 1980 with TE Score (0.86) to the year 1984 and 1985 with TE Score (1.0). Asides from these years, the port achieved technical efficiency only in 1987 and 2004 pre-concession era while she achieved scale efficiency in the production years 1987, 1988, 2003, and 2004. However, there was a fluctuation in technical progress all through the production periods at the port. On the contrary, the port eventually operated on a stable optimal scale from 2010 to 2015 post concession era after the later stability in scale efficiency achieved from the beginning of the 1980s era till mid-1980s. Thus, this reflects the optimal utilization of superstructure concessioned to the terminal operators while the fluctuating technical efficiency could be as a result of the inabilities of some terminal operators to embrace more technologies in their operations. Technical efficiency is a prerequisite for economic efficiency when a firm produces the maximum output with the lowest quantity of inputs required. Scale efficiency or scale effect this measures how a DMU can utilize its production scale. This is an alternating and new developed model to determine the return to scale (RTS) nature of a DMU. When other basic methods i.e., CRS envelopment model and VRS multiplier model failed to test a DMU'S RTS nature especially when DEA models have the alternate optimal solution, scale efficiency was adopted to solve the issue.

\subsection{Trend analysis of Tin Can Island port complex productivity}

Figure 3: CRS - Technical Efficiency (Input-oriented) and CRS - Scale Efficiency (Input-oriented) at Tin Can Island Port Complex from 1980 - 2015

Input-Oriented Technical, Pure Technical and Scale Efficiencies at Tin Can Island Port from Operation year 1980 to 2015

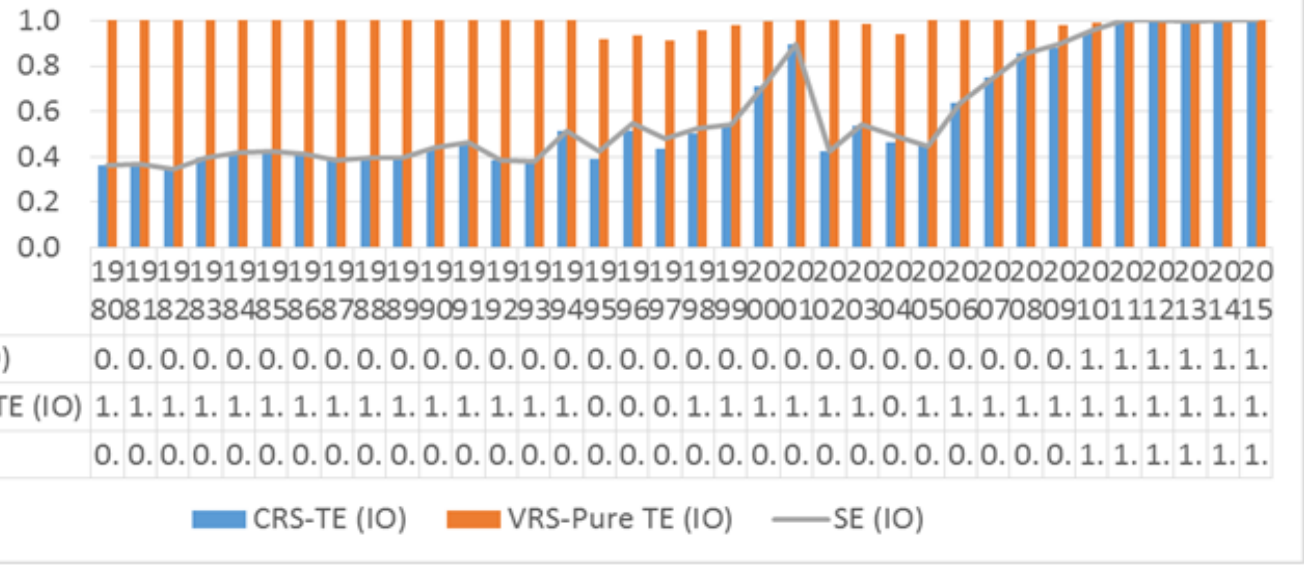


Figure 3 depicts the trends of input-oriented technical, pure technical and scale efficiencies at Tin Can Island Port from the year 1980 to 2015. The port was technically inefficient in the pre-concession years of 1980 to 2004 with the highest efficiency score of 0.7 achieved in the year 2000 and the least efficiency score is 0.4 achieved in the years $1980,1981,1983,1984,1985,1986,1987,1988,1989,1990$, 1992 e.tc. This reflects serious technical problems at the Port during this era. However, the technical efficiency score rose from 0.4 with scale efficiency in the post-concession year of 2007 to an efficiency score of 1.0 in the operation year 2010. It is observed that the port maintained the efficiency score till 2015. The Port experienced managerial issues in the operation years 1994, 1995, 1996 and 2004. The port lacked scale optimization all through the pre-concession years but adjusted to scale in the year 2011 and maintained till the year 2015.

Figure 4: CRS-Technical Efficiency (Output-oriented) and CRS-Scale Efficiency (Outputoriented) at Tin Can Island Port Complex from 1980 - 2015

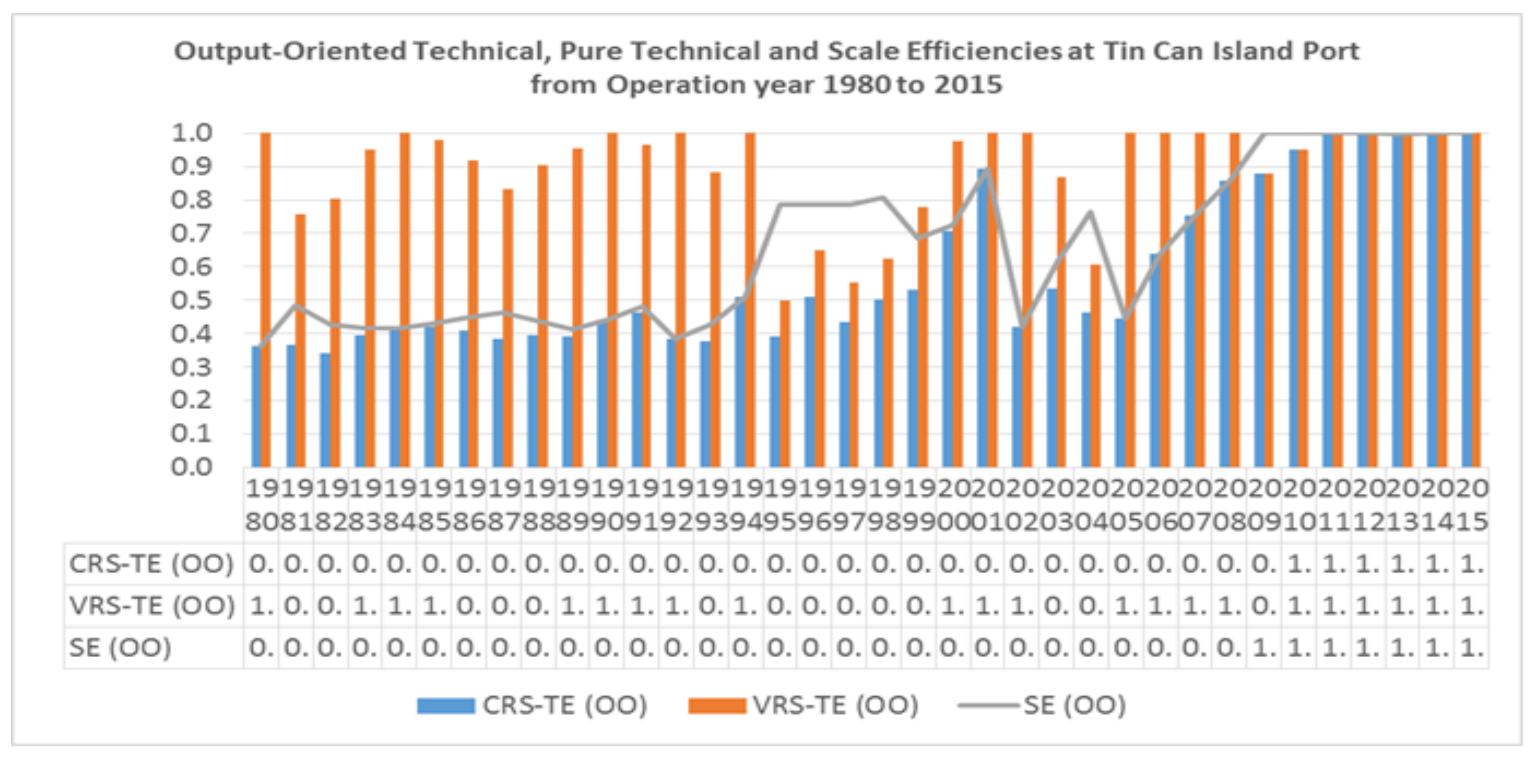

Figure 4 above shows the trends of output-oriented technical, pure technical and scale efficiencies at Tin Can Island Port from the year 1980 to 2015. The port was technically inefficient in the preconcession years of 1980 to 2009 with the highest efficiency score of 0.9 achieved in the year 2001 and the least efficiency score is 3.5 achieved in the year 1980 and 1989. This reflects serious technical problems at the Port during these two years. However, the technical efficiency score together with scale efficiency rose from 0.4 in the post-concession year of 2005 to an efficiency score of 1.0 in the operation year 2011. It is observed that the Port maintained the efficiency score till 2015. 


\subsection{Trend Analysis of Rivers Port Complex Productivity} Figure 5: CRS - Technical Efficiency (Input-oriented) and CRS - Scale Efficiency (Input-oriented)
at Rivers Port Complex from 1980 - 2015

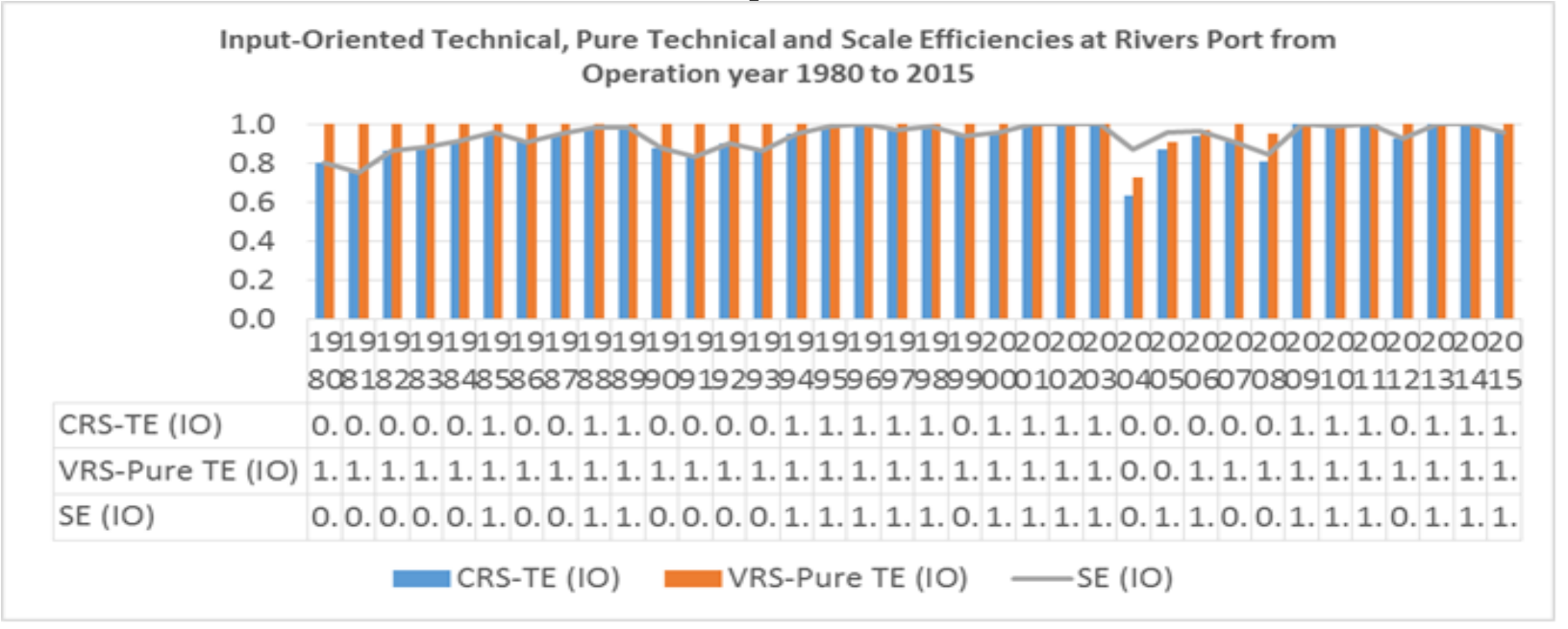

The trends for technical and scale efficiencies are fluctuating in which out of the 26 pre-concession years, River Port was inefficient for 16 years while out of the 10 post concession years, the port was inefficient for 4 years. In the years 2004 and 2005, the Port was not managerially efficient with scores 0.7 and 0.9 respectively.

Figure 6: CRS - Technical Efficiency (Output-oriented) and CRS - Scale Efficiency (Outputoriented) at Rivers Port Complex from 1980 - 2015

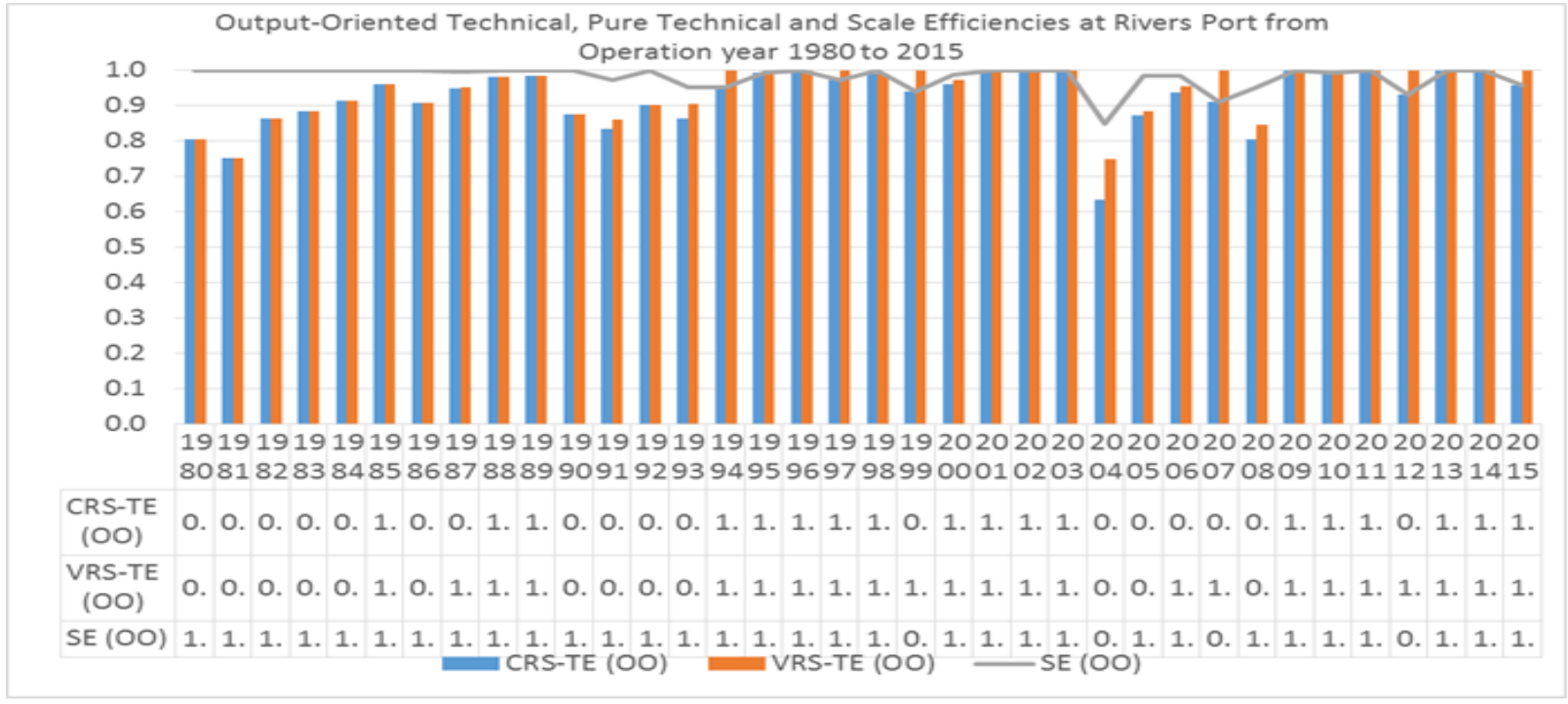

For output optimization, there was a fluctuation in the trend of technical efficiency. Thus, DMU/the pre-concession year of 1985, 1988, 1989, 1994, 1995, 1996, 1997, 1998, 2000, 2001, 2002 and 2003 were technically and managerially efficient in terms of output wise and DMU/post concession year of 2009, 2010, 2011, 2013, 2014 and 2015 were technically efficient. However, the Port experienced managerial inefficiency only during post concession era in the year 2008. The Port was scale efficient in all the operation years except the years 1999, 2004, 2007 and 2012. 


\subsection{Trend Analysis of Delta Port Complex Productivity}

Figure 7: CRS - Technical Efficiency (Input-oriented) and CRS - Scale Efficiency (Input-oriented) at Delta Port Complex from 1980 - 2015

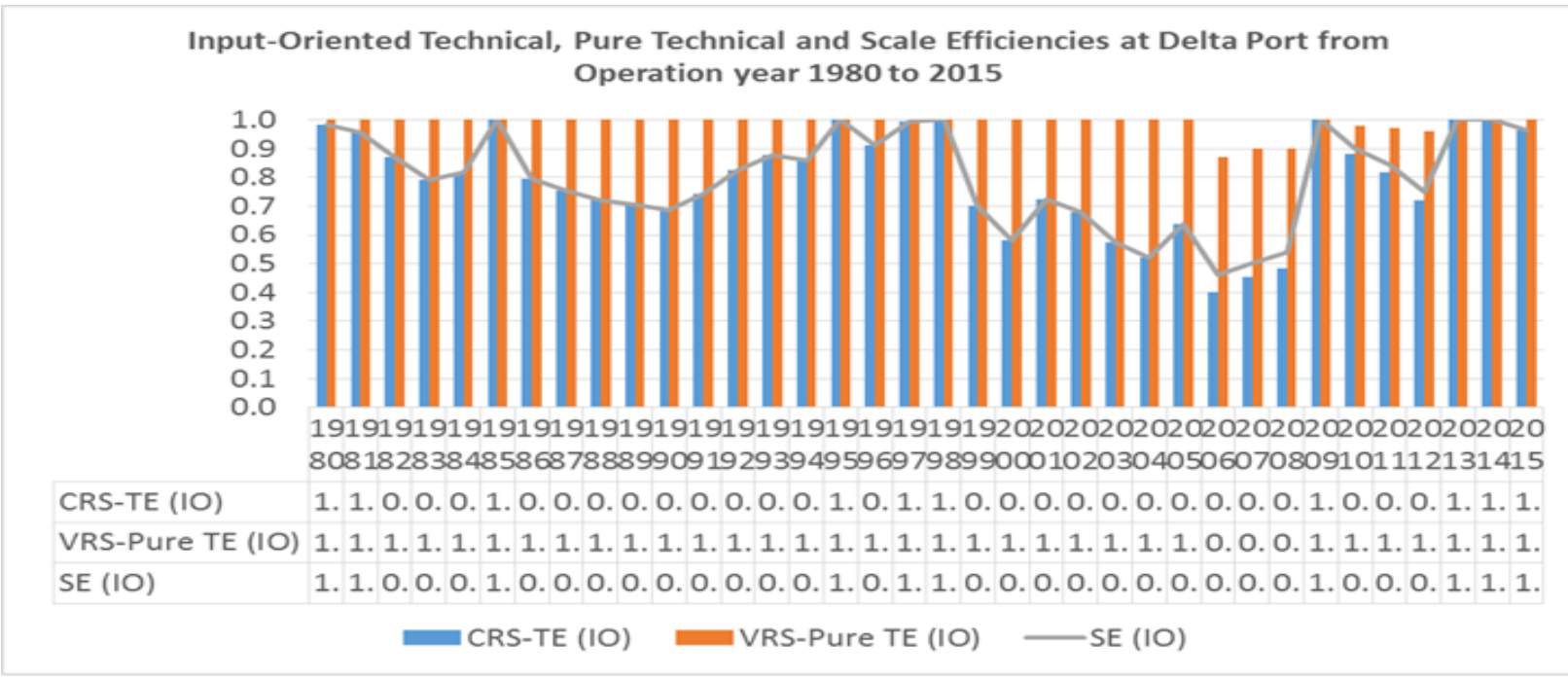

Figure 7 above depicts the trends of input-oriented technical, pure technical and scale efficiencies at Delta Port from the year 1980 to 2015 in which the port maintained technical and scale efficiency score 1.0 in the pre-concession era year of 1980 but dropped to score 0.8 in 1982 and 1983. Fluctuation in technical and scale efficiency occurs all through the pre-concession era. Hence, there were drastic drops in the technical and scale efficiency from score 1.0 ((the year 1998) to score 0.4. This drop trend was followed by unsteady and unstable increases inefficiencies between post concession year of 2006 and 2013. Subsequently, stable efficiency was achieved from the year 2013 to 2015. Though, the Port was managerially efficient all through the operation years understudy with an efficiency score of 1.0.

Figure 8: CRS - Technical Efficiency (Output-oriented) and CRS - Scale Efficiency (Outputoriented) at Delta Port Complex from 1980 - 2015

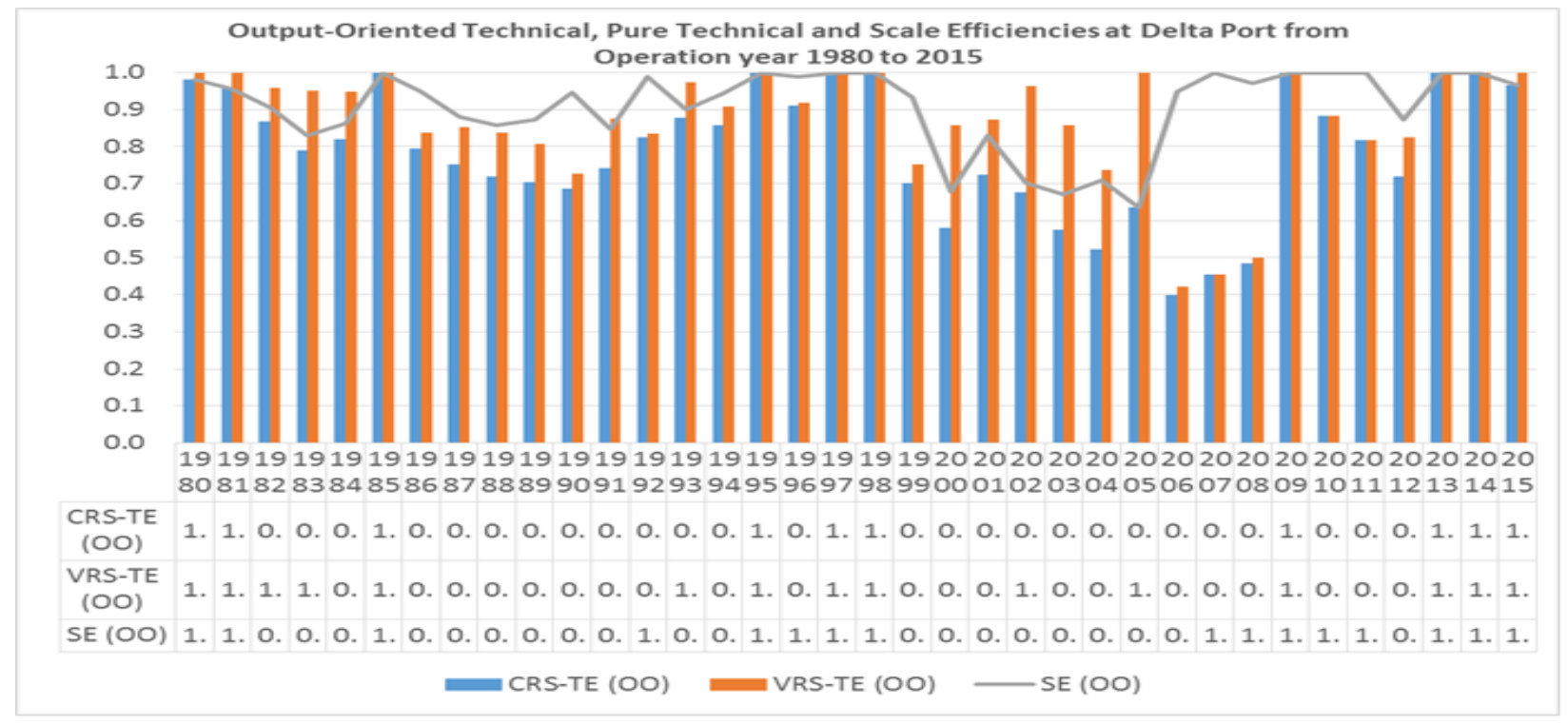


Figure 8 above depicts the trends of output-oriented technical, pure technical and scale efficiencies at Delta Port from the year 1980 to 2015 in which the port fluctuations in technical and scale efficiency scores over the period. Though the fluctuation in technical and scale efficiency occurs more often during the pre-concession period. The post-concession period in the port is more stable as it concerns technical and scales efficiency scores.

\subsection{Trend analysis of Onne port complex productivity}

\section{Figure 9: CRS - Technical Efficiency (Input-oriented) and CRS - Scale Efficiency (Input-oriented) at Onne Port Complex from 1980 - 2015}

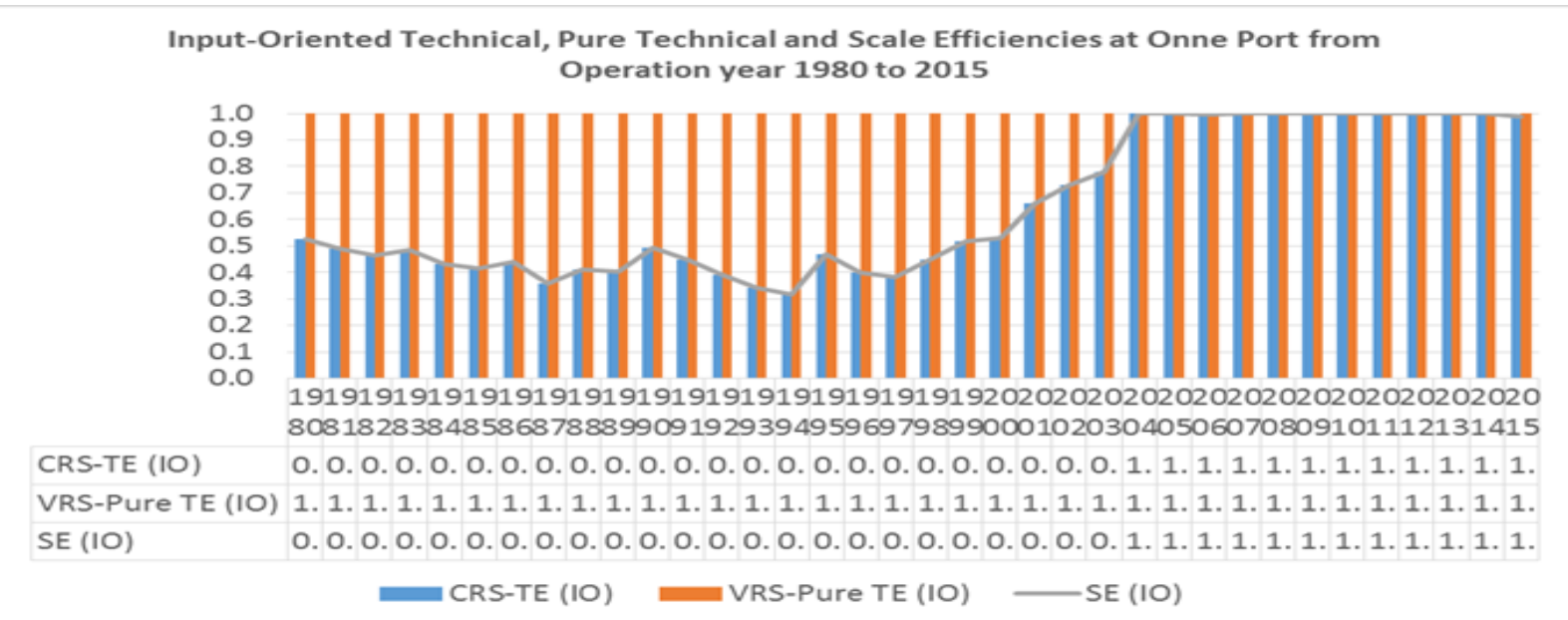

Figure 9 depicts the trends of input-oriented technical, pure technical and scale efficiencies at Onne Port from the year 1980 to 2015 in which the port was technically and scale inefficient in all the pre-concession years (1980 to 2003) with technical efficiency scores less than 1.0 respectively but she started experiencing technical efficiency from the year 2004 when the Port was concessioned till the year 2015 with score 1.0 Hence, the Port was wasteful in terms of input utilization throughout the preconcession years of operation understudy and was technically efficient all through the concessioning period (2004 - 2015). This may be as a result of the involvement of private concessionaires in terminal operations of the port. This consistency and best performance reflect a high level of technology employed among these concessionaires and appropriate input mix. It is also observed that the port experienced managerial efficiency with a score of 1.0 all through the operation years under study.

\section{Figure 10: CRS - Technical Efficiency (Output-oriented) and CRS - Scale Efficiency (Output- oriented) at Onne Port Complex from 1980 - 2015}

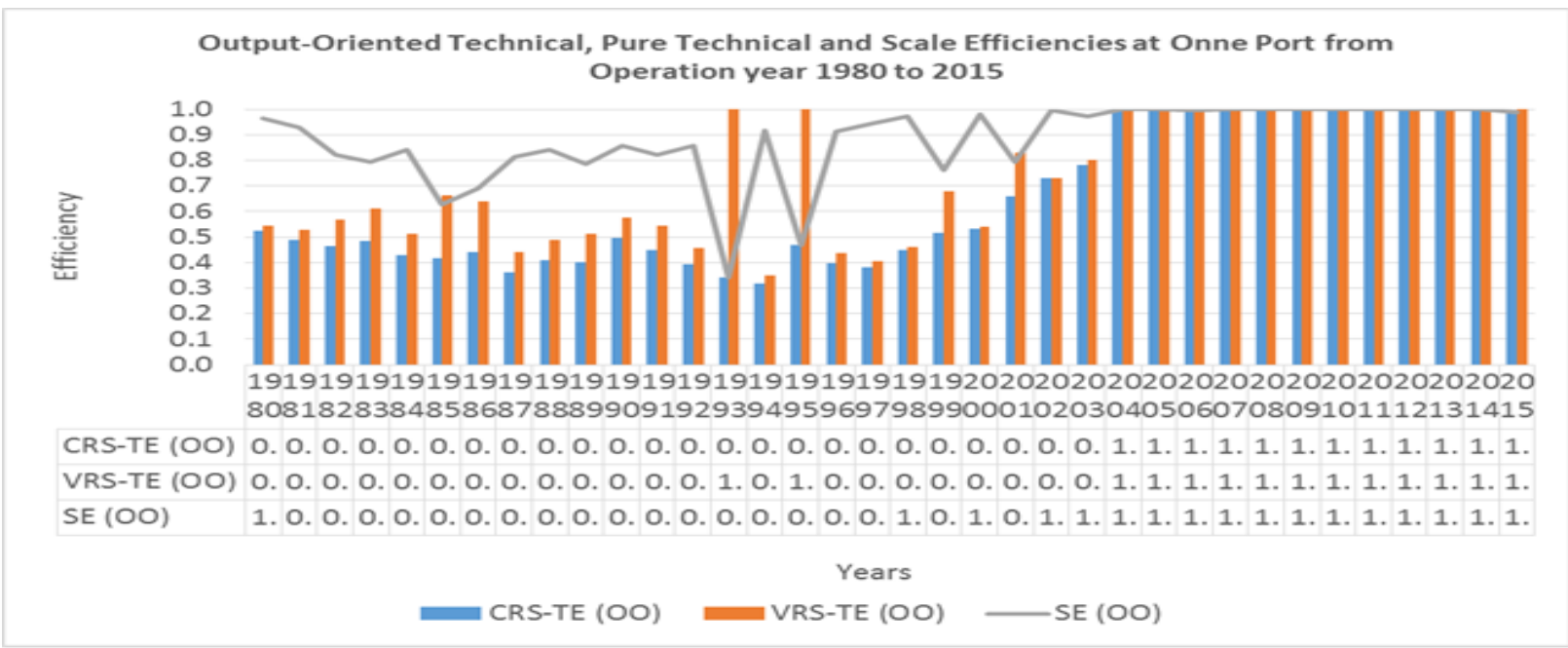


Figure 10 above depicts the output-oriented efficiencies at Onne Port from the year 1980 to 2015 . Thus, the Port was not technically efficient in terms of output maximization to constant levels of inputs used. The Port was able to maximize its outputs only in the post-concession years 2004, 2005, 2006, 2007, 2008, 2009, 2010, 2011, 2012, 2013, 2014 and 2015 and the Port was able to manage its resources optimally in pre-concession years 1993 and 1995 and in the post-concession years 2004, 2005, 2006, 2007, 2008, 2009, 2010, 2011, 2012, 2013, 2014 and 2015. The Port had scale efficiency of 1.0 in year 1998, 2000, 2002, 2003, 2004, 2005, 2006, 2007, 2008, 2009, 2010, 2011, 2012, 2013, 2014 and 2015.

\subsection{Trend analysis of Calabar Port complex productivity}

\section{Figure 11: CRS - Technical Efficiency (Input-oriented) and CRS - Scale Efficiency (Input- oriented) at Onne Port Complex from 1980 - 2015}

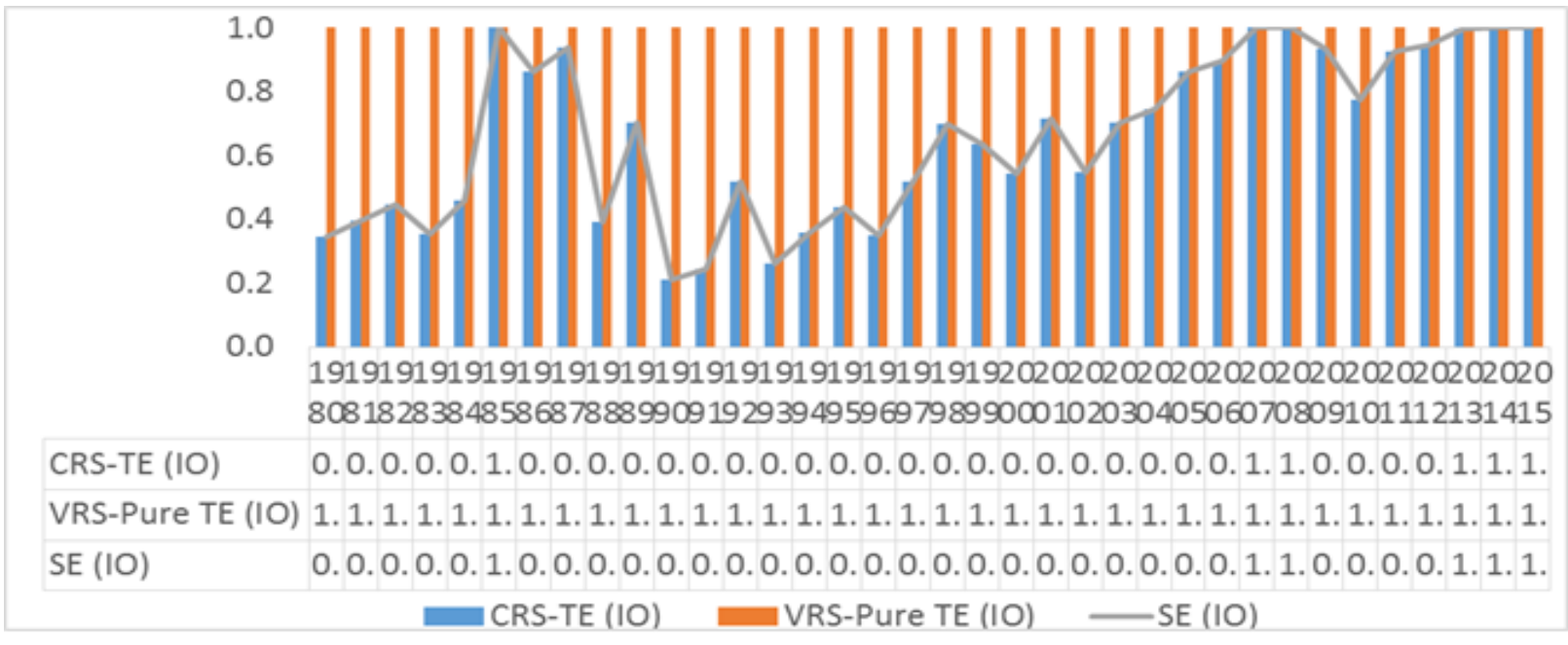

Figure 11 above depicts the trends of input-oriented technical, pure technical and scale efficiencies from the year 1980 to 2015 in which the port was technically efficient only in the preconcession era year of 1985 with technical efficiency score 1.0 and post-concession era year of 2007, 2008, 2013, 2014 and 2015 with technical efficiency score 1.0 while the port had pure technical efficiency or managerial efficiency score of 1.0 all through the operation years. Hence, the Port had been wasteful in terms of input minimization for fifteen (15) years out of the sixteen years (16) understudy before concessioning and for four (4) years out of the eight (8) years after concession. The Port was able to operate on optimal scale size only in the pre-concession year of 1985 with a scale efficiency score of 1.0 and post-concession era year of 2007, 2008, 2013, 2014 and 2015 with a scale efficiency score of 1.0. The technical inefficiencies experienced by Calabar Port brought about inefficiencies in inputs' sizes utilization which implies that inputs used can either be minimized to obtain the realized outputs for the specific inefficient operation years or be used to achieve more outputs.

Figure 12 depicts the trends of output-oriented technical, pure technical and scale efficiencies at Calabar Port from the year 1980 to 2015 in which the port was technically efficient only in the preconcession year of 1985 with technical efficiency score 1.0 and post-concession years of 2007, 2008, 2013, 2014 and 2015 with technical efficiency score 1.0 thus this is in line with the analysis of figure 6 that output can be maximized with the level of inputs resources used in the inefficient years. The port was managerially efficient in pre-concession years 1984 1985, 1987, 1989 and 1997 and in the postconcession years 2007, 2008, 2013, 2014 and 2015 with a score of 1.0. This implies that the ship traffic or calls were not managed properly to achieve the required or predetermined throughputs in the managerial inefficient years. Also, the Port experienced scale inefficiency in terms of output maximization in the pre-concession years of 1984, 1989, 1995, 1997 and 1998 and the post-concession year of 2012 due to impacts of technical inefficiencies on her operation in the years. 


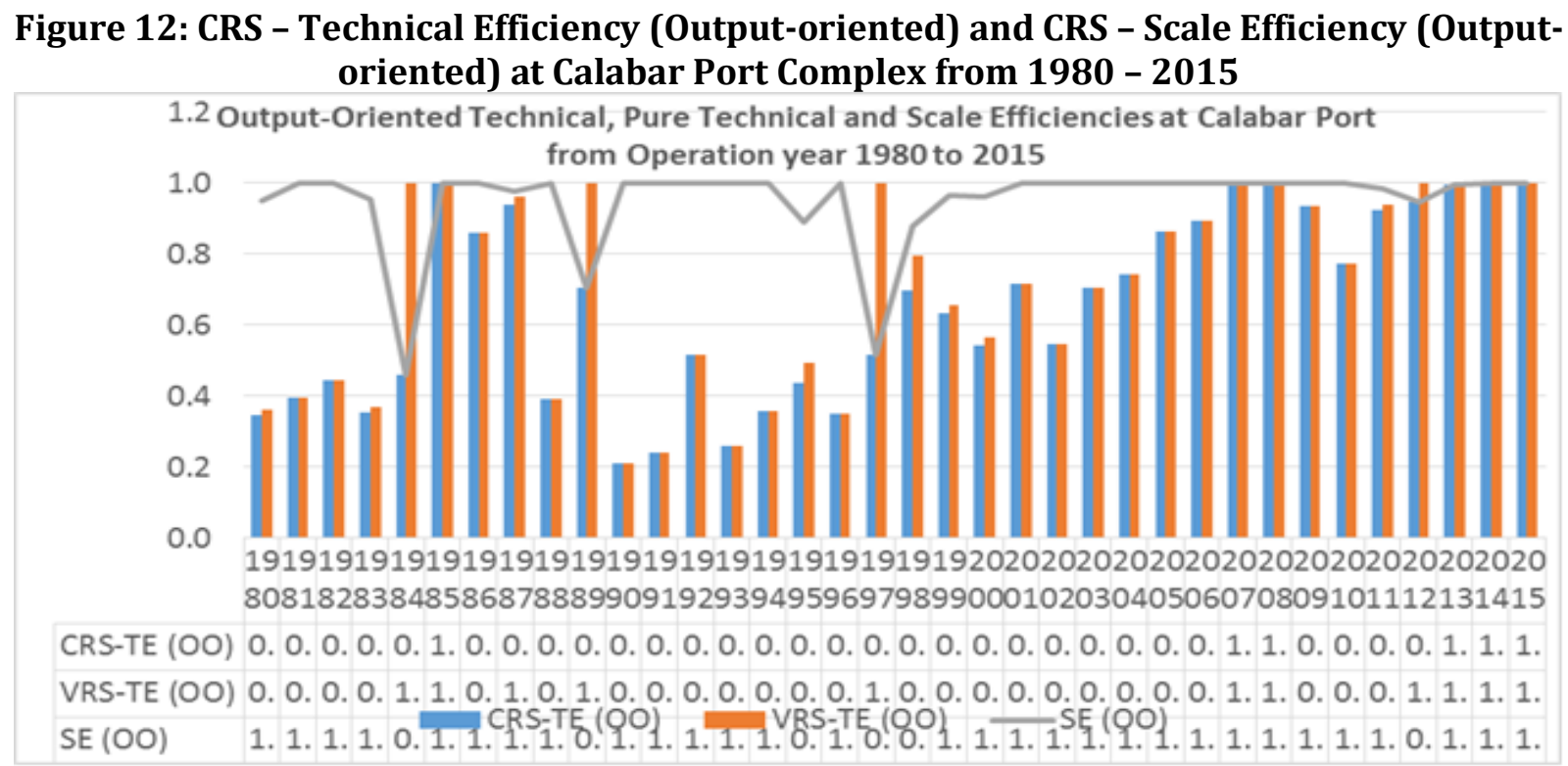

\section{Conclusion}

The study was able to assess only the trend analysis of productivity at individual Nigerian ports i.e., the studying of productivity of Nigerian ports changes for the firm over a period because of many factors which are not limited to variation in cargo operations, geographical location e.tc. Hence, the impacts of concessioning were felt at Onne Port and Tin Can Island Port because the level of technical and scale efficiencies was very unacceptable in the pre-concession period as it was recorded that the only highest level of efficiency (0.8) the Port achieved in the pre-concession was in the year 2003 while Tin Can Island Port achieved technical and scale efficiency of 0.9 only in the pre-concession year 2001. However, they were able to utilize their input resources consistently to the optimal level to produce adequate or required outputs' quantities for more than five (5) consecutive post concession years with technical, scale and managerial efficiency scores of 1.0 respectively. They were able to use their scale size optimally in the post concession years with a scale efficiency score of 1.0 respectively. Rivers, Delta, Calabar and Lagos Port experienced unstable efficiencies in the post concession era. However, Delta Port experienced the least efficiency score in the pre-concession era in the years 2006, 2007 and 2008 with scores of $0.4,0.5$ and 0.5 respectively in terms of input minimization and output maximization. The most efficient operation year in Lagos Port Complex is the year 2011 and the least inefficient operation years are the year 1992,1993, 1994 and 1999 with an efficiency score of year 0.8. The most efficient operation year in Tin Can Island Port is the year 2014 and the least inefficient year is 1982 with an efficiency score of 0.3 .

The most efficient operation year in River Port is the year 2001 while the least inefficient year is 2004 with an efficiency score of 0.6. The most efficient operation year in Delta Port is the year 2013 and the least inefficient operation year in Delta Port is 2006 with an efficiency score of 0.4 . The most efficient operation year in Calabar Port is the year 2007 and the least inefficient year is the year 1991 with a score of 0.2. The most efficient years in Onne Port are the years 2005 and 2009 while the least inefficient year are 1993 and 1994. Hence, all Nigerian Ports achieved the highest level of efficiency in the post concession year except River Port that had the highest level of efficiency in the year 2001. Hence, the impacts of concessioning were felt at Onne Port and Tin Can Island Port because the level of technical and scale efficiencies was very unacceptable in the pre-concession period as it was recorded that the only highest level of efficiency (0.8) the Port achieved in the pre-concession was in the year 2003 while Tin Can Island Port achieved technical and scale efficiency of 0.9 only in the pre-concession year 2001. However, they were able to utilize their input resources consistently to the optimal level to produce adequate or required outputs' quantities for more than five (5) consecutive post concession years with technical, scale and managerial efficiency scores of 1.0 respectively. They were able to use their scale size optimally in the post concession years with a scale efficiency score of 1.0 respectively.

Rivers, Delta, Calabar and Lagos Port experienced unstable efficiencies in the post concession era. However, Delta Port experienced the least efficiency score in the pre-concession era in the years 2006, 
2007 and 2008 with scores $0.4,0.5$ and 0.5 respectively in terms of input minimization and output maximization. The most efficient operation year in Lagos Port Complex is the year 2011 and the least inefficient operation years are the year 1992, 1993, 1994 and 1999 with an efficiency score of year 0.8. The most efficient operation year in Tin Can Island Port is the year 2014 and the least inefficient year is 1982 with an efficiency score of 0.3. The most efficient operation year in River Port is the year 2001 while the least inefficient year is 2004 with an efficiency score of 0.6 . The most efficient operation year in Delta Port is the year 2013 and the least inefficient operation year in Delta Port is 2006 with an efficiency score of 0.4. The most efficient operation year in Calabar Port is the year 2007 and the least inefficient year is the year 1991 with a score of 0.2 . The most efficient years in Onne Port are the years 2005 and 2009 while the least inefficient year are 1993 and 1994. Hence, all Nigerian Ports achieved the highest level of efficiency in the post concession year except River Port that had the highest level of efficiency in the year 2001.

\section{Funding}

Not applicable

\section{Conflicts of interest/Competing interests}

Not applicable

\section{Availability of data and material}

Not applicable

\section{Code availability}

Not applicable

\section{Authors' information (optional)}

Not applicable

\section{Acknowledgements}

We thank the anonymous reviewers for their suggestions.

\section{Citation information}

Nze, O. N., Okeudo, G. N., \& Ejem, E. A. (2021). Trend analysis of the productivity of Nigerian seaports. Journal of Sustainable Development of Transport and Logistics, 6(2), 81-95. doi:10.14254/jsdtl.2021.62.5 .

\section{References}

Antle, J. M., \& Capalbo, S. M. (1988). An introduction to recent developments in production theory and productivity measurement. Agricultural Productivity: Measurement and Explanation, 17-95. https://doi.org/10.4324/9781315673318-12

Beškovnik, B. (2008). Measuring and increasing the productivity model on maritime container terminals. Pomorstvo, 22(2), 171-183.

Bhagavath, V. (2006). Technical efficiency measurement by data envelopment analysis: an application in transportation. Alliance Journal of Business Research, 2(1), 60-72.

Chung, K. C. (1993). Port performance indicators. Transportation, Water and Urban Development Department, the World Bank.

Courbois, R., \& Temple, P. (2001). La mthode des "Comptes de surplurs" et ses applications macroeconomiques. 160 des Colect, INSEE, Series C (35), 100. 
De Monie, G. (1987). Measuring and evaluating port performance and productivity. UNCTAD Monograph on Port Management. UNCTAD/SHIP/494 (6).

DMR. (2017). Review of maritime transport. Drewry Maritime Research.

Eatwell, J. M., \& Newman, P. (1991). The New Palgrave: A Dictionary of Economics, 3, 4, 12. Tokyo: Macmillan. https://doi.org/10.9780230279803

Gboyega, A. O. (2005). Concept and measurement of productivity. Ibadan: Department of Economics, The University of Ibadan.

Golany, B., \& Roll, Y. (1989). An application procedure for DEA.Omega, 17(3), 237-250. https://doi.org/10.1016/0305-0483(89)90029-7

Kumar, S. A., \& Suresh, N. (2009). Operations management. New Age International.

Kurosawa, K. (1975). An aggregate index for the analysis of productivity and profitability. Omega, 3(2), 157-168. https://doi.org/10.1016/0305-0483(2000)90115-2

Marlow, P. B., \& Casaca, A. C. P. (2003). Measuring lean ports performance. International Journal of Transport Management, 1(4), 189-202. https://doi.org/10.1016/j.ijtm.2003.12.002

Nigeria Port Authority (NPA). (2012). Apapa Amended Part 1. Lagos: Nigeria Port Authority.

Nigeria Port Authority. (2015). Annual Report. Abuja: Nigeria Port Authority.

Odeck, J., \& Schøyen, H. (2009). Assessing the relative efficiency and productivity of Norwegian seaport: An abstract on stochastic frontier approach. Norwegian University of Science and Technology, 146.

Owens, G. C. (1978). Improving Total Productivity: MBO Strategies for Business, Government, and Notfor-Profit Organizations. Journal of Accountancy (pre-1986), 145(000005), 88.

Pineda, A. J. (1990). A multiple case study research to determine and respond to management information needs using total-factor productivity measurement. Virginia Polytechnic Institute and State University.

Robert, E. H., \& Marc, L. (2009). Productivity Measurement. In E. H. Robert, Economics Principles and Applications, 242-263. New York: Springer.

Saari, S. (2006). Productivity theory and measurement in business. Finland: Espoo, Finland: European Productivity Conference.

Sarıca, K., \& Or, I. (2007). Efficiency assessment of Turkish power plants using data envelopment analysis. Energy, 32(8), 1484-1499. https://doi.org/10.1016/j.energy.2006.10.016

Sumanth, J. D. (1984). Productivity engineering and management. New York: McGraw Hill.

Tongzon, J., \& Heng, W. (2005). Port privatization, efficiency and competitiveness: Some empirical evidence from container ports (terminals). Transportation Research Part A: Policy and Practice, 39(5), 405-424. https://doi.org/10.1016/j.tra.2005.02.001

Udabah, S. (2000). Productivity and Growth, 67-93.

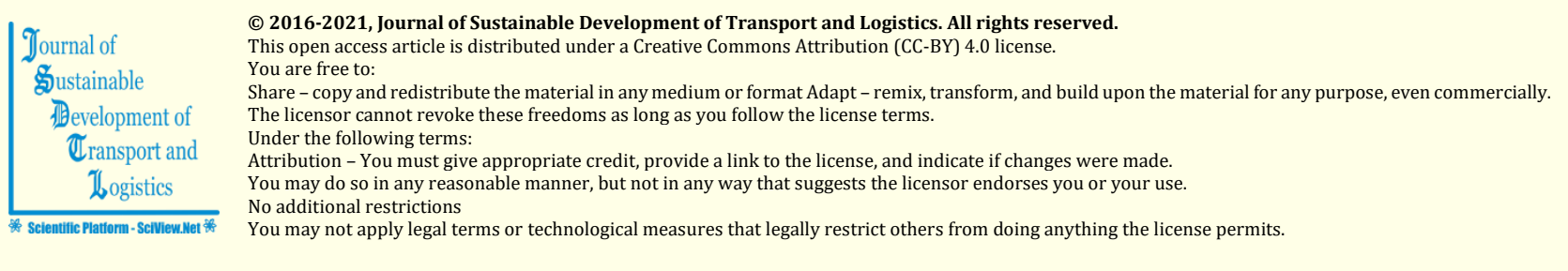

Journal of Sustainable Development of Transport and Logistics (ISSN: 2520-2979) is published by Scientific Publishing House "CSR", Poland, EU and Scientific Publishing House "SciView", Poland, EU

Publishing with JSDTL ensures:

- Immediate, universal access to your article on publication

- High visibility and discoverability via the JSDTL website

- Rapid publication

- Guaranteed legacy preservation of your article

- Guaranteed legacy preservation of your article

Submit your manuscript to a JSDTL at https://jsdtl.sciview.net/ or submit.jsdtl@sciview.net 